\title{
somatent

\section{A fundamental shift in the melt processes of Arctic sea ice}

Jeremy Wilkinson ( $\sim$ jpw28@bas.ac.uk)

British Antarctic Survey

Martin Doble

Polar Scientific Ltd

Lovro Valcic

Bruncin

Gaelle Veyssiere

British Antarctic Survey

\section{Sylvia Cole}

Woods Hole Oceanographic Institution

Luc Rainville

Applied Physics Laboratory, University of Washington

Craig Lee

Applied Physics Laboratory, University of Washington

John Hargrove

Center for Southeastern Tropical Advanced Remote Sensing, University of Miami

Julia DiLeo

Center for Southeastern Tropical Advanced Remote Sensing, University of Miami

Hans Graber

Center for Southeastern Tropical Advanced Remote Sensing, University of Miami

\section{Article}

Keywords: Arctic sea ice, melt cycle, marine ecosystem

Posted Date: September 8th, 2020

DOI: https://doi.org/10.21203/rs.3.rs-63411/v1

License: (c) (1) This work is licensed under a Creative Commons Attribution 4.0 International License.

Read Full License 
A fundamental shift in the melt processes of Arctic sea ice Jeremy Wilkinson ${ }^{1 *}$, Martin Doble ${ }^{2}$, Lovro Valcic ${ }^{3}$, Gaelle Veyssiere ${ }^{1}$, Sylvia T. Cole $^{4}$, Luc Rainville ${ }^{5}$, Craig Lee ${ }^{5}$, John Hargrove ${ }^{6}$, Julia DiLeo ${ }^{6}$, Hans Graber ${ }^{6}$

Affiliations:

${ }^{1 *}$ British Antarctic Survey, Cambridge, UK.

${ }^{2}$ Polar Scientific Ltd, Appin, Scotland, UK.

${ }^{3}$ Bruncin, Zagreb, Croatia.

${ }^{4}$ Woods Hole Oceanographic Institution, Woods Hole, USA.

${ }^{5}$ Applied Physics Laboratory, University of Washington, Seattle, USA.

${ }^{6}$ Center for Southeastern Tropical Advanced Remote Sensing, University of Miami, Miami, USA.

As the Arctic Ocean transitions into a seasonally ice-covered ocean, the processes that govern the sea ice melt cycle will undergo a fundamental shift. The summer melt cycle passes through several stages, such as snowmelt, meltpond formation and drainage, and basal melting; normally with surface melt processes occurring well before basal melt. Monitoring of atmospheric, sea ice and oceanographic properties from autonomous buoys deployed across the Beaufort Sea, combined with targeted satellite imagery, reveal a fundamental restructuring of these melt processes within the seasonal ice zone - where basal melt occurs before surface melt. We find this seemingly unremarkable change accelerates the basal melting of sea ice by ten-fold, as well as transforming the timing and flux of freshwater and heat into the upperocean. These processes play a pivotal role in determining upper-ocean stratification, and when combined with a modification of the under-ice light field, it could impact marine ecosystem function.

Arctic sea ice is a key climate indicator and many of its properties have been monitored for decades, during which time we have observed changes in many aspects of its lifecycle. From a decline in sea ice extent in all seasons (1), to a reduction in its 
thickness (2), a decline in multiyear ice and its replacement by first-year ice (3) and variations in its drift (4). In summer, these changes have led to the sea ice edge retreating further northwards, and a more fractured state for the sea ice that remains (5). These changes are consistent with an Arctic Ocean transitioning from a perennial sea-ice cover to a seasonal ice regime (6). The Beaufort Sea epitomizes this transition as it now has a predominately seasonal ice cover, and in the spring and summer large expanses of the Beaufort are subject to low concentrations of sea ice, or even ice-free conditions in its southernmost regions.

Ice-albedo feedback is regarded as the most important mechanism controlling surface and basal melt processes (7). The basis of this is the stark contrast in albedo between the snow on the sea ice $(>0.8$, see $(8))$ and that of open-water $(\sim 0.07$, see $(9))$. Surface melt transitions through three broad stages (10). During Stage 1 the snow melts and the meltwater spreads out over the surface forming large lakes, because the ice is initially impermeable to meltwater. Stage 2 is characterised by the rapid drainage of these lakes, via the opening of macroscopic flaws in the ice, reducing the size and area covered by meltponds. Stage 3 involves processes such as surface ablation and meltpond evolution that occur late in the season, and are beyond the scope of this study.

Basal melt occurs through a different process. As the season advances the ice pack weakens, becomes more divergent and fractured, producing larger areas of open water. Because of the very low albedo of the ocean surface it preferentially absorbs solar radiation, warming the upper-ocean. Once the ocean temperature rises above its freezing-point basal melting begins (11), which provides a near-constant freshwater flux (until the ice is completely melted). 
Traditionally the Arctic Ocean in summer consisted of high ice concentrations of perennial ice, with only the peripheries experiencing short periods of lower ice concentration or open-water. With limited breakup and divergence sea ice melt was predominately controlled by surface melt processes, with a lesser amount being basal melt (12). However, the Arctic Ocean is presently transitioning towards a seasonal ice cover, and understanding how this influences the timing of surface and basal melt processes and its impact on the upper-ocean is a priority (13-14).

\section{Data}

In Autumn 2018, several autonomous buoys were deployed on the sea ice within the northern regions of the Beaufort Sea. These systems monitored key atmospheric, oceanic and sea ice properties over an annual cycle to better understand the evolution of the upper-ocean stratification process in one of the fastest changing regions of the Arctic Ocean. They were deployed in two different configurations (see Table 1).

(i) Three clusters of three autonomous buoys (an $\mathrm{ITP}^{1}, \mathrm{AOFB}^{2}$ and $\mathrm{WIMBO}^{3}$ ) were co-located on three separate floes: Cluster 1 (C1), Cluster 2 (C2) and Cluster3 (C3). Only the ITP and WIMBO systems were used in this study.

(ii) Two single WIMBO buoys deployed on separate floes: Solo 1(S1) and Solo 2 (S2).

Near daily Synthetic Aperture Radar (SAR) satellite images, centred on each Cluster and Solo site, were obtained in order to provide a broader spatial context to the in situ

\footnotetext{
${ }^{1}$ Ice Tethered Profiler (ITP): Profiles of temperature, salinity and velocity are obtained from a profiler that crawls along a weighted wire suspended from a surface buoy (15-16).

${ }^{2}$ Autonomous Ocean Flux Buoy (AOFB): monitors velocity, temperature, salinity, and the vertical turbulent fluxes of heat, salt, and momentum in the upper-ocean along with vertical profiles of ocean currents.

${ }^{3}$ Weather, waves, Ice Mass Balance, Ocean buoy (WIMBO): monitors metrological parameters including incoming solar radiation, wind speed and direction, air temperature; ice and snow properties via an ice mass balance (IMB) senor string; and upper-ocean properties via a $200 \mathrm{~m}$ temperature and salinity chain.
} 
results. Products used included the publicly available Sentinel-1 imagery, as well as specifically targeted high-resolution imagery: RADARSAT-2, COSMO-SkyMed, and TerraSAR-X. OSISAF ice concentration (17) was used to monitor the ice conditions on a synoptic-scale

\section{Methods}

The dates associated with the start of snowmelt (Stage 1) and meltpond drainage (Stage 2) were obtained from the analysis of near-daily SAR imagery that was targeted at the Clusters and Solo platforms. The identification of these two stages is made possible because SAR image intensity is attenuated as the scattering surface (either snow or ice) becomes wet (Dierking, 2013). When the snow on the ice surface melts, its appearance in a SAR image darkens due to reduced backscatter, and then when the meltponds drain, it brightens again due to enhanced backscatter (See supplementary Fig. S1).

To identify the start of basal melt we identified, within each IMB record, the first date at which the thickness of the ice bottom had been at least $10 \mathrm{~cm}$ less than its winter maximum for three consecutive days. As basal melting is related to the break-up of the ice pack, we also ascertained the date when the OSISAF ice concentration at a site dropped below $90 \%$ for at least three consecutive days.

Both the ITPs and WIMBOs observed the temperature and salinity structure of the upper-ocean (0-65 m). On each ITP, (i) a Seabird microCAT located at a fixed-depth of $5 \mathrm{~m}$ sampled every 15 minutes, and (ii) the profiling CTD sampled every 3 hours with $1 \mathrm{~m}$ vertical resolution. Each of the five WIMBO systems measured air-iceocean temperatures through the meteorological sensors, the IMB (every $2 \mathrm{~cm}$ ), and the $200 \mathrm{~m}$ T-Chain. The T-Chain measured upper-ocean temperature $(0-65 \mathrm{~m})$ with a 
vertical resolution of $0.25 \mathrm{~m}$ and salinity at discrete depths $(5 \mathrm{~m}$ and $25 \mathrm{~m}$ ). Whilst the IMB sampled hourly, the data from other sensors were obtained every 10 minutes in summer and hourly in winter. All data shown covers the period May 1 to July 31, 2019.

\section{Results}

The drift tracks of the three clusters (C1, C2 and C3) and the two Solo sites (S1 and S2) can be seen in Fig. 1, and the contrasting behaviour in ice concentration along their tracks in Fig. 2. The northern most clusters $(\mathrm{C} 1$ and $\mathrm{C} 2)$ remained within high concentrations of perennial ice in the northern Beaufort Sea for the entire year. Their drift tracks were virtually identical, with a complete ice cover remaining until the end of June, after which the concentration dipped to around $80 \%$ before rising again in autumn. The more southerly cluster (C3) drifted east before turning south, following a similar drift track to S1 and S2. It remained in relatively high ice concentrations until mid-June (>80\%), after which it reduced to around $60 \%$, recovered slightly, before melting out completely in September. The two Solo platforms (S1, S2), which were deployed at slightly lower latitudes, also drifted eastwards, before more rapidly moving south. The ice around these systems experienced an early and near-continuous reduction in ice concentration from mid-May, eventually melting completely in late July and August respectively. This discrepancy between the near continuous perennial ice-cover around clusters $\mathrm{C} 1$ and $\mathrm{C} 2$ (a proxy for the traditional Arctic system), and the seasonal ice surrounding C3, S1 and S2 (a proxy for a future seasonal Arctic system) provides an exceptional opportunity to investigate the evolution and impact of melt within these distinct systems.

When considering the development of the sea ice melt cycle we must determine the relative timings of (a) snowmelt, (b) drainage of meltpond (c) pack break-up and (d) 
basal melt at each site. The dates of each of these are displayed by markers within Figures 2, 4 and 5, and are summarised along with the initial snow and ice conditions in Table 1. All deployment sites had a similar thickness of snow, between $0.15-0.22$ $\mathrm{m}$, and an ice thickness of around $1 \mathrm{~m}$, except $\mathrm{C} 3$ which had a thickness of over $2 \mathrm{~m}$. Our analysis suggests uniformity in the timing of snowmelt and meltpond drainage throughout the range of latitudes of this study $\left(\sim 70^{\circ} \mathrm{N}\right.$ to $\left.80^{\circ} \mathrm{N}\right)$; snowmelt in mid-tolate June and meltpond drainage in early July. There is however considerable divergence in the timing of basal melt. For the southernmost systems S1 and S2 basal melting started in mid-June, for C3 which was slightly further north it was late June, and the end of July for the northern most C2. Basal melt for $\mathrm{C} 1$ could not be determined as the co-deployed WIMBO stopped transmitting in mid-April, but is expected to be like $\mathrm{C} 2$. This latitudinal component to the start of basal melt is also apparent in the reduction in sea ice concentration (Fig. 2 and Table 1). Taken together we find that the seasonal ice zone (C3, S1, S2) experiences an early and continuous reduction in sea ice concentration combined with an early start to basal melting, whilst the perennial ice zone $(\mathrm{C} 1, \mathrm{C} 2)$ sees a delay in the reduction in ice concentration and a deferred start to basal-melting, in this case more than a month later. This variation in timing is consistent with our knowledge of the impact of the ice-albedo feedback mechanism.

Fig. 3 shows the contrasting evolution in cartoon form. Differences between the two regimes are driven by the availability of open water to absorb downwelling solar radiation. It is important to point out that contrasts are not the result of more solar radiation being present at the surface at lower latitudes - quite the reverse, as radiometer measurements from the WIMBO systems showed the northern sites have greater surface insolation $\left(+45 \mathrm{~W} / \mathrm{m}^{2}\right)$ than the southern sites (attributed to less 
cloudiness at higher ice concentration sites). Nor are air temperatures significantly different between the two cases $\left(0.4^{\circ} \mathrm{C}\right)$; see supplementary Fig. S2.

\subsection{Consequences for the ocean}

Given the stark contrasts between the melt processes within the seasonal and perennial ice zones, we can expect the consequences for the upper-ocean to be similarly varied. Here we interpret changes to the ocean mixed layer that is directly in contact with the sea ice in May - July, and during these months it is isolated by strong stratification from the (geographically variable) water masses below. By focusing on the evolution of oceanic properties and the timings of key melt-events at each site, we can better understand how different melt processes influence upper-ocean properties.

Fig. 4 shows time/depth evolution of the temperature and salinity structure at a high latitude perennial and the lower latitude seasonal zones, as monitored by sensors on the WIMBOs and ITPs for May through July. As no ITPs were deployed at the Solo sites, we used $\mathrm{C} 3$ to represent the seasonal melt cycle and $\mathrm{C} 2$ to represent the traditional melt cycle. In addition, Fig. 5 shows the deviation of temperature and salinity from their May 1 values over the subsequent three months, along with the deviation of temperature $(T)$ from its freezing point $\left(\mathrm{T}_{\mathrm{f}}\right)$ at $5 \mathrm{~m}$ depth over the same period, for all Clusters and Solo sites. May 1 was chosen because on this date all sites had a continuous ice cover (see Fig. 2), air temperatures were well below freezing, and there was no evidence melt processes had begun.

Though the two northern clusters ( $\mathrm{C} 1$ and $\mathrm{C} 2)$ were separated by around $100 \mathrm{~km}$ the evolution of upper-ocean properties were similar. For the most of May and June the water temperature remained near $T_{f}$, but after snowmelt and subsequent meltpond drainage events we see a slight freshening and warming of the upper-ocean. This 
steady change in salinity and temperature continued after bottom melt started at the end of July. Overall, we see a $0.2^{\circ} \mathrm{C}$ rise in temperature and a reduction in salinity of less than 0.5 between May and July. The traditional melt process can be described as having a slight, but relatively consistent, impact on the upper-ocean.

At lower latitude sites (S1 and S2) we find the changes in temperature and salinity more pronounced and varied. The combination of melt processes with the influence of other water masses, such as shelf-waters, during their southward drift makes interpretation more complex, and for this reason we include the deviation from freezing point $\left(\mathrm{T}-\mathrm{T}_{\mathrm{f}}\right)$ in Fig. 5. The Solo sites were deployed very close to each other, and took similar southerly trajectories, albeit with S1 drifting south of S2. The first striking difference with the northerly clusters is the early start and speed to the warming of the upper-ocean. Between mid-May and the start of snowmelt in midJune there was an increase in temperature of more than $0.5^{\circ} \mathrm{C}$ above its freezing point, more than double that seen by the northerly clusters over the entire three months. As the change in temperature was combined with almost no change in salinity, it suggests the influence of solar warming through lead openings. This assumption is corroborated by the reduction in ice concentration which first dropped below $90 \%$ in mid-May, and reduced to around $75 \%$ by mid-June (Fig. 2 ).

Cluster C3 was located between the northerly clusters and the southerly Solo sites, and its easterly deployment meant that its subsequent drift passed close to the Canadian shelf, and so potentially influenced by shelf-waters. The freshening without deviation from the freezing point that began in mid-May is suggestive of drifting into a region with slightly fresher water properties. Around the start of June there is an increase in temperature above its freezing point of about $0.15^{\circ} \mathrm{C}$, before snowmelt was initiated in mid-June. This is consistent with the ice concentration around C3 
dropping to below $90 \%$ at the end of May, again suggesting solar radiation entering the water column through leads. Shortly afterwards basal melt starts (23 June), and the salinity begins to reduce quickly, but the deviation from freezing point temperature remains steady at about $0.15^{\circ} \mathrm{C}$. However, the most significant change in temperature coincides with the start of meltpond drainage (4 July), which sees patches of relatively high temperature $\left(1.5^{\circ} \mathrm{C}\right.$ above $\left.\mathrm{T}_{\mathrm{f}}\right)$ water reaching down to almost $20 \mathrm{~m}$ depth (see Fig. 4), similar events were seen in S1 and S2. These warm patches could represent local drainage plumes rapidly mixed into the upper 10s of meters of the ocean, or more likely indicate that the $\mathrm{C} 3$ platforms drifted though several melt-water plumes that previously entered the ocean from non-local points. In situ measurements of the temperature of water with meltponds suggest it can warm above $0^{\circ} \mathrm{C}(18)$. Note that the ice thickness at the $\mathrm{C} 3$ site went to zero on August 2, which indicates that the floe either melted or broke up.

\section{Discussion}

Our results suggest the high latitude regions of the Arctic are still representative of perennial ice cover, where surface melt dominates over basal melt, and melting follows the traditional regimented and distinct cycle of Snowmelt-Pond formation/drainage-Basal melt. The lower latitudes, on the other hand, represent a seasonal ice regime with a reordered melt cycle in which basal melt occurs significantly earlier in the season, in our case almost coincident with snowmelt. We anticipate that the continued early retreat of Arctic ice will further emphasize the importance of basal melt, and will favour a seasonal melt cycle that follows the path of Basal melt—Snowmelt—Pond formation/drainage.

Which of these two melt cycles dominate appears to be predicated on its ice concentration history. Our data suggests that the early availability of low-albedo 
open-water is the major factor in warming the upper-ocean and initiating basal melt. This assumption is supported by Kashiwase et al., (19) who suggested that the albedo mismatch between ice and water could be a major factor that enhances summer sea ice retreat, caused by early-season divergent motion. An early break up and divergence of the ice pack will favour a seasonal melt cycle, whereas a late season divergence of the pack will result in a more traditional melt cycle.

Under the traditional melt progression, the impact of surface and basal melt on the upper-ocean is modest and occurs over several months, which gives longer to slowly mix this freshwater downwards within the surface layer. Intriguingly, in our study the drainage of meltponds had a much smaller influence on the upper-ocean structure at the high latitude sites, despite all Clusters and Solo platforms being surrounded by a similar snow cover (see Table 1). The reason for this reduced effect could be related to the mechanisms controlling the way meltwater flows through the sea ice. It has been suggested by Polashenski et al., (10) that the pathways through the sea ice may be plugged by the refreezing of meltwater, and that this process is highly dependent on ice temperature, salinity, and the initial pore size. The median ice temperature when the meltponds drained on 3 July for northern site C2 and southern site S2 was $1.29^{\circ} \mathrm{C}\left( \pm 0.02^{\circ} \mathrm{C}\right)$ and $-0.87^{\circ} \mathrm{C}\left( \pm 0.07^{\circ} \mathrm{C}\right)$ respectively. Thus, with colder ice it is possible that plugging is more prevalent within the high-latitude regions, limiting the upper-ocean response. A secondary effect that may introduce more meltwater to the southern sites is the fractured nature of the sea ice. When snow melts the resultant meltwater spreads horizontally across the surface of the sea ice until it reaches the edge of a floe, where it cascades into the ocean. This process is not as prevalent in regions of higher ice concentration as the floes are bigger meaning the area-to- 
perimeter ratio of the floes is considerably larger, thus a higher volume of meltwater will be retained on the floe.

Under a seasonal melt cycle, the timing between the surface and basal melt processes occurs earlier and is considerably narrowed. This allows for substantially more heat (through solar input and meltpond drainage) and freshwater (through basal melt and meltpond drainage) to enter the upper-ocean earlier in the season, and over a condensed period. The contrast between regions of perennial and seasonal ice becomes more pronounced when comparing basal melt rates. Between May and July $\mathrm{C} 2$ experiences and average melt rate of a millimetre a day $(1.1 \mathrm{~mm} /$ day $)$ whilst $\mathrm{C} 3$ experiences over the same period almost a centimetre a day $(9.7 \mathrm{~mm} /$ day $)$, see Fig.4 for location of ice bottom. Furthermore, regions of moderate ice concentration, like C3, will have more efficient coupling between the atmosphere and ocean, thus increasing the transfer of momentum into the upper-ocean and enhancing turbulent mixing (20).

A further impact of a change in the timing and sequence of the melt cycle will be on the under-ice light field. Snow has a very high light-extinction coefficient, up to $40 \mathrm{~m}^{-}$ ${ }^{1}$ compared with the sea ice of around $1 \mathrm{~m}^{-1}(21-22)$. Therefore, as the snow melts the intensity of the under-ice light field increases, which is a major factor for photosynthesis by phytoplankton and ice algae (23). In situ measurements have shown that rapid snow melting events may result in doubling the amount of solar irradiance under the ice (24), but it is only when significant areas of open-water are present, later in the season, that the upper-ocean light field will substantially increase on a large scale. This suggests that under the traditional melt cycle the upper-ocean light field will provide a gradual increase as the season advances. The seasonal melt cycle however, will allow more light to directly enter the water column much early in the 
season, because of the break-up and divergence of the pack. Importantly, under that seasonal scenario the reduction in ice concentration occurs before the snow has melted, thus the under-ice light field will still diminished. How the large mismatch in light intensity between open-water regions and under-ice regions influence development of phytoplankton and algae in the Arctic is not clear. This situation is more akin to the seasonal retreat of Antarctic sea ice.

\section{Conclusion/Summary}

Whilst many of the processes mentioned have been previously studied, it is only by using autonomous air-ice-ocean observations across a latitudinal range, with targeted satellite imagery, that we can provide this comprehensive overview of Arctic melt processes. Together they provide a powerful tool to demonstrate the previously unseen paradigm shift that is taking place in the melt sequence of Arctic sea ice that is summarised by Fig. 3, thereby ensuring basal melt dominates ice loss in this 'new Arctic' analogue.

The reorganisation of sea ice melt processes represents a fundamental change in the Arctic melt regime, one that substantially enhances basal melt and influences the timing and the nature of the evolution of the upper-ocean properties and the under-ice light field. These processes play a crucial role in regulating algal growth and phytoplankton blooms, and hence the transfer of energy and matter to higher trophic levels (25). A pan-Arctic shift towards a seasonal melt cycle has the potential to induce a mismatch between the coordination of algal growth, phytoplankton blooms, and zooplankton production, thus disrupting ecosystem dynamics at all trophic levels. 
Acknowledgments: This work was supported by an Office of Naval Research (ONR) Departmental Research Initiative called Stratified Ocean Dynamics in the Arctic (SODA), and the work presented here is supported by multiple ONR grants. We would like to acknowledge contributions from all members of the SODA team, and are grateful to captain, officers and crew of the USCGC Healy.

Author contributions: JW conceived the idea behind the study, JH, JDL, HG, LR prepared the SAR images, ITP data prepared by SC, WIMBO data by JW, MD and LV. All authors contributed to methodology, analysis, and the writing and reviewing of the manuscript.

Competing interests: Authors declare no competing interests.

Data and materials availability: All data, code, and materials used in the analysis is available to any researcher for purposes of reproducing or extending the analysis.

\section{References:}

1. Meier, Walt. N., Greta K. Hovelsrud, Bob E.H. van Oort, Jeffrey R. Key, Kit M. Kovacs, Christine Michel, Christian Haas, Mats A. Granskog, Sebastian Gerland, Donald K. Perovich, Alexander Makshtas and James D. Reist, Arctic sea ice in transformation: A review of recent observed changes and impacts on biology and human activity, Rev. Geophys., 52, 185-217 (2014).

2. Lindsay, R. and Schweiger, A.: Arctic sea ice thickness loss determined using subsurface, aircraft, and satellite observations, The Cryosphere, 9, 269-283, (2015).

3. Comiso, J. C. Large decadal decline of the Arctic multiyear ice cover. Journal of Climate, 25(4), 1176-1193 (2012).

4. Spreen, G., Kwok, R., and Menemenlis, D. Trends in Arctic sea ice drift and role of wind forcing: 1992-2009, Geophys. Res. Lett., 38, L19501, ( 2011).

5. Strong, C., and Rigor, I. G., Arctic marginal ice zone trending wider in summer and narrower in winter, Geophys. Res. Lett., 40, 4864-4868, (2013).

6. Lebrun, M., Vancoppenolle, M., Madec, G., and Massonnet, F. Arctic sea-ice-free season projected to extend into autumn, The Cryosphere, 13, 79-96 (2019).

7. Perovich, D. K. et al. Increasing solar heating of the Arctic Ocean and adjacent seas, 1979-2005: Attribution and role in the ice-albedo feedback. Geophys. Res. Lett. 34, L19505 (2007).

8. Perovich, D. K. \& Polashenski, C. Albedo evolution of seasonal Arctic sea ice. Geophys. Res. Lett. 39, L08501 (2012).

9. Pegau, W. and C. Paulson The albedo of Arctic leads in summer, Ann. Glaciol., 33, 221-224 (2001).

10. Polashenski, C., Perovich, D., and Courville, Z. The mechanisms of sea ice melt pond formation and evolution, J. Geophys. Res., 117, C01001, (2012).

11. Maykut, G. A. \& Perovich, D. K. The role of shortwave radiation in the summer decay of a sea ice cover. J. Geophys. Res. Oceans 92, 7032-7044 (1987). 
12. Maykut, G. A. \& Untersteiner, N. Some results from a time-dependent thermodynamic model of sea ice. J. Geophys. Res. 76, 1550-1575 (1971).

13. Carmack, E., Polyakov, I., Padman, L., Fer, I., Hunke, E., Hutchings, J., Jackson, J., Kelley, D., Kwok, R., Layton, C., Melling, H., Perovich, D., Persson, O., Ruddick, B., Timmermans, M.-L., Toole, J., Ross, T., Vavrus, S., \& Winsor, P. Toward quantifying the increasing role of oceanic heat in sea ice loss in the new Arctic. Bulletin of the American Meteorological Society, 96(12), 2079-2105 (2015).

14. Gallaher, S. G., Stanton, T. P., Shaw, W. J., Cole, S. T., Toole, J. M., Wilkinson, J. P., Maksym, T., and Hwang, B. Evolution of a Canada Basin ice-ocean boundary layer and mixed layer across a developing thermodynamically forced marginal ice zone, J. Geophys. Res. Oceans, 121, 6223-6250 (2016).

15. Toole, J. M., R. A. Krishfield, M.-L. Timmermans, and A. Proshutinsky The IceTethered Profiler: Argo of the Arctic, Oceanogr., 24, 126-135, (2011).

16. Cole, S.T., F.T. Thwaites, R.A. Krishfield, and J.M. Toole, Processing of Velocity Observations from Ice-Tethered Profilers. Proceedings Oceans 2015 MTS/IEEE, Washington, D.C. Oct 19-22 (2015).

17. Tonboe, R., Lavelle, J., Pfeiffer, R., and Howe, E. Product User Manual for OSISAF Global Sea Ice Concentration, available at:

http://osisaf.met.no/docs/osisaf_cdop3_ss2 pum ice-conc_v1p6.pdf (2016).

18. Kashiwase, H., Ohshima, K.I., Nihashi, S. et al. Evidence for ice-ocean albedo feedback in the Arctic Ocean shifting to a seasonal ice zone. Sci Rep 7, 8170 (2017).

19. Martin, T., Steele, M., \& Zhang, J. Seasonality and long-term trend of Arctic Ocean surface stress in a model. Journal of Geophysical Research, Oceans, 119, 1723-1738. (2014).

20. Perovich, D. K. and A.J. Gow A quantitative description of sea ice inclusions, $J$. Geophys. Res., 101( C8), 18327-18343, (1996).

21. Light, B., D.K. Perovich, M.A. Webster, C. Polashenski and R. Dadic Optical properties of melting first-year Arctic sea ice, J. Geophys. Res. Oceans, 120, 76577675, (2015).

22. Arrigo, Kevin R., Perovich, Donald K., Pickart, Robert S., Brown, Zachary W., van Dijken, Gert L., Lowry, Kate E., Mills, Matthew M., Palmer, Molly A., Balch, William M., Bahr, Frank, Bates, Nicholas R., Benitez-Nelson, Claudia, Bowler, Bruce, Brownlee, Emily, Ehn, Jens K., Frey, Karen E., Garley, Rebecca, Laney, Samuel R., Lubelczyk, Laura, Mathis, Jeremy, Matsuoka, Atsushi, Mitchell, B. Greg, Moore, G.W.K., Ortega-Retuerta, Eva, Pal, Sharmila, Polashenski, Chris M., Reynolds, Rick A., Schieber, Brian, Sosik, Heidi M., Stephens, Michael and Swift, James H. Massive phytoplankton blooms under Arctic sea ice. Science, 336 (6087), p1408 (2012).

23. Lei, R., Zhang, Z., Matero, I., Cheng, B., Li, Q., \& Huang, W. Reflection and transmission of irradiance by snow and sea ice in the central Arctic Ocean in summer 2010. Polar Research, 31(1), 17325 (2012).

24. Wassmann, P., and M. Reigstad. Future Arctic Ocean seasonal ice zones and implications for pelagic-benthic coupling. Oceanography 24(3):220-231 (2011). 


\begin{tabular}{|c|c|c|c|c|c|c|c|}
\hline $\begin{array}{l}\text { Platform identifier } \\
\text { (listed from north to } \\
\text { south at deployment) }\end{array}$ & $\begin{array}{l}\text { Co-deployed } \\
\text { Platform/s }\end{array}$ & & $\begin{array}{l}\text { Initial snow and sea ice } \\
\text { thickness (m) }\end{array}$ & $\begin{array}{l}\text { Date ice concentration } \\
\text { dropped to below } 90 \% \\
\text { from OSISAF data }\end{array}$ & $\begin{array}{l}\text { Date basal melt } \\
\text { started, as seen by } \\
\text { IMB }\end{array}$ & $\begin{array}{l}\text { Date snowmelt started } \\
\text { as seen by SAR imagery }\end{array}$ & $\begin{array}{lr}\text { Date } & \text { meltpond } \\
\text { drainage } & \text { started as } \\
\text { seen by SAR imagery }\end{array}$ \\
\hline $\begin{array}{l}\text { Cluster } 2 \\
\text { (perennial ice cover) }\end{array}$ & $\begin{array}{l}\text { WIMBO4, } \\
\text { AOFB42 }\end{array}$ & ITP104, & $\begin{array}{l}\text { Snow: } 0.17 \mathrm{~m} \\
\text { Ice: } 1.44 \mathrm{~m} \\
\left(80.53^{\circ} \mathrm{N}, 136.64^{\circ} \mathrm{W}\right)\end{array}$ & $\frac{29 \text { June } 2019}{\left(81.55^{\circ} \mathrm{N} 126.03^{\circ} \mathrm{W}\right)}$ & $\frac{28 \text { July } 2019}{\left(81.77^{\circ} \mathrm{N} 128.51^{\circ} \mathrm{W}\right)}$ & $\frac{\text { 15 June } 2019}{\left(81.83^{\circ} \mathrm{N} 125.67^{\circ} \mathrm{W}\right)}$ & $\frac{\text { 3 July } 2109}{\left(81.49^{\circ} \mathrm{N} 126.42^{\circ} \mathrm{W}\right)}$ \\
\hline $\begin{array}{l}\text { Cluster } 1 \\
\text { (perennial ice cover) }\end{array}$ & $\begin{array}{l}\text { WIMBO3, } \\
\text { AOFB41 }\end{array}$ & ITP105, & $\begin{array}{l}\text { Snow: } 0.22 \\
\text { Ice: } 1.16 \mathrm{~m} \\
\left(80.12^{\circ} \mathrm{N}, 141.22^{\circ} \mathrm{W}\right)\end{array}$ & $\frac{\text { o3 July } 2019}{\left(80.94^{\circ} \mathrm{N} 130.41^{\circ} \mathrm{W}\right)}$ & $\begin{array}{l}\text { N/A } \\
\text { (WB03 lost early) }\end{array}$ & $\frac{\text { 19 June } 2019}{\left(81.31^{\circ} \mathrm{N} 130.26^{\circ} \mathrm{W}\right)}$ & $\frac{\text { 26 June-3 July 2019* }}{\left(80.94^{\circ} \mathrm{N} 130.41^{\circ} \mathrm{W}\right)}$ \\
\hline $\begin{array}{l}\text { Cluster } 3 \\
\text { (seasonal ice cover) }\end{array}$ & $\begin{array}{l}\text { WIMBO2, } \\
\text { AOFB40 }\end{array}$ & ITP103, & $\begin{array}{l}\text { Snow: } 0.16 \mathrm{~m} \\
\text { Ice: } 2.35 \mathrm{~m} \\
\left(78.90^{\circ} \mathrm{N} 134.90^{\circ} \mathrm{W}\right)\end{array}$ & $\frac{30 \text { May } 2019}{\left(78.28^{\circ} \mathrm{N} 126.90^{\circ} \mathrm{W}\right)}$ & $\frac{23 \text { June } 2019}{\left(77.37^{\circ} \mathrm{N} 127.15^{\circ} \mathrm{W}\right)}$ & $\frac{\text { 15 June } 2019}{\left(77.93^{\circ} \mathrm{N} 127.86^{\circ} \mathrm{W}\right)}$ & $\frac{28 \text { June-4 July 2019* }}{\left(76.95^{\circ} \mathrm{N} 129.97^{\circ} \mathrm{W}\right)}$ \\
\hline $\begin{array}{l}\text { Solo } 1 \\
\text { (seasonal ice cover) }\end{array}$ & WIMBO1 & & $\begin{array}{l}\text { Snow: } 0.15 \mathrm{~m} \\
\text { Ice: } 0.93 \mathrm{~m} \\
\left(78.11^{\circ} \mathrm{N}, 138.12^{\circ} \mathrm{W}\right)\end{array}$ & $\frac{\text { 19 May } 2019}{\left(74.70^{\circ} \mathrm{N} 129.34^{\circ} \mathrm{W}\right)}$ & $\frac{14 \text { June } 2019}{\left(73.65^{\circ} \mathrm{N} 131.97^{\circ} \mathrm{W}\right)}$ & $\frac{24 \text { May-13 June 2019* }}{\left(73.81^{\circ} \mathrm{N} 132.20^{\circ} \mathrm{W}\right)}$ & $\frac{26 \text { June-3 July 2019* }}{\left(71.32^{\circ} \mathrm{N} 130.26^{\circ} \mathrm{W}\right)}$ \\
\hline $\begin{array}{l}\text { Solo } 2 \\
\text { (seasonal ice cover) }\end{array}$ & WIMBO6 & & $\begin{array}{l}\text { Snow: } 0.17 \mathrm{~m} \\
\text { Ice: } 0.92 \mathrm{~m} \\
\left(77.92^{\circ} \mathrm{N}, 138.98^{\circ} \mathrm{W}\right)\end{array}$ & $\frac{14 \text { May } 2019}{\left(76.47^{\circ} \mathrm{N} 129.81^{\circ} \mathrm{W}\right)}$ & $\frac{15 \text { June } 2019}{\left(76.00^{\circ} \mathrm{N} 130.92^{\circ} \mathrm{W}\right)}$ & $\begin{array}{l}\text { N/A } \\
\text { (SAR not available) }\end{array}$ & $\begin{array}{l}\text { N/A } \\
\text { (SAR not available) }\end{array}$ \\
\hline
\end{tabular}

Table 1. Table identifying the buoys associated with each cluster and solo platform (working from high latitude to low latitude), the ice conditions and location of deployment, the dates and location associated with the reduction of ice concentration below 90\%, the start of basal melt (identified from IMB data), the start of snowmelt (identified from SAR analysis) and the drainage of meltponds (identified from SAR analysis). The timelines associated with these three processes are represented by the colours green (the process happened first), yellow (second), orange (third) and red (forth).

381 * Daily SAR not available, therefore a range of dates given that covers the gap in SAR data. In these cases, the latest date was used. 


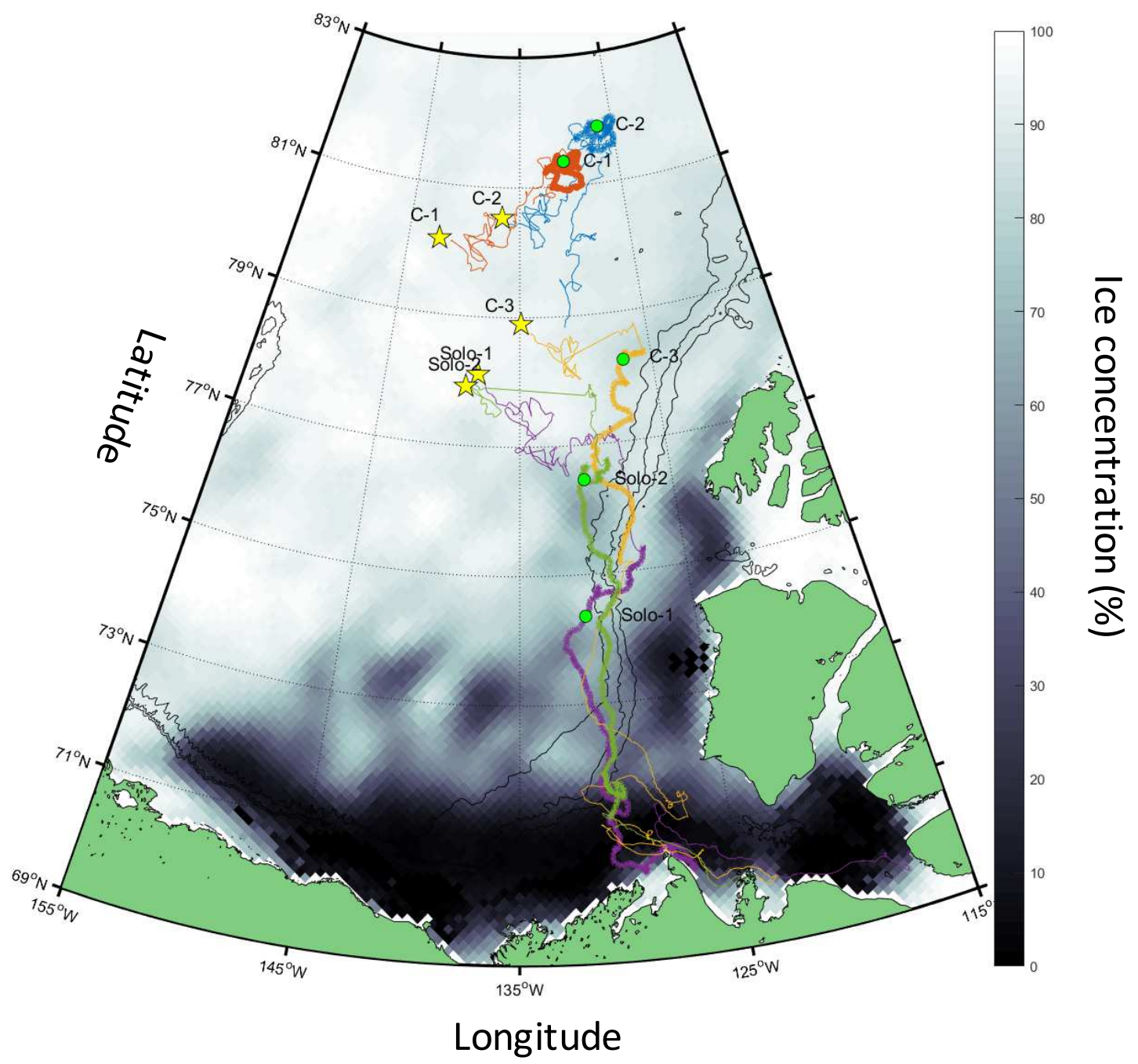

Fig. 1. Drift tracks for Cluster 1 (red), Cluster 2 (blue), Cluster 3 (yellow), Solo1 (purple), Solo 2 (green). The thicker lines represent the drift track from 1 May to 31 July. Notice that Cluster 1 and 2 stay in the north, whilst all the other systems drift southward over time (especially S1 and S2 which are close to the coast by the end of July). The yellow star represents their deployment location, the green circle represents their location on 1 June 2019, the same date at the underling OSISAF ice concentration image (which runs from white or $100 \%$ ice concentration through to black $0 \%$ or open water). The $2000 \mathrm{~m}, 1000 \mathrm{~m}, 500 \mathrm{~m}$ bathymetric contour lines (in black) are also shown. 


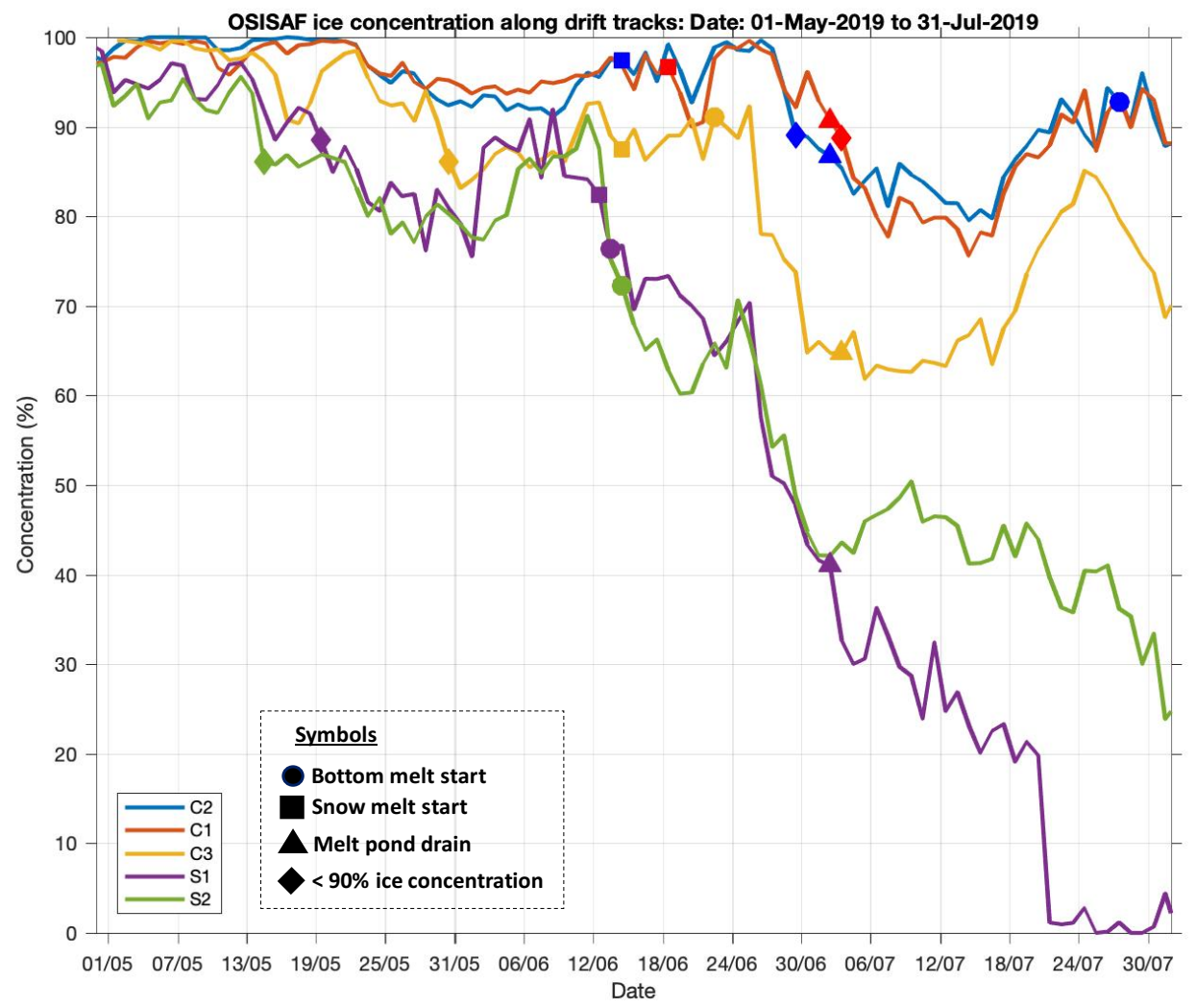

Fig. 2. Graph showing ice concentration against date (from May 1 to July 31, 2019) along the track of each Cluster and Solo platform. Also shown is start of start of the basal melt (circle), snowmelt (square), when the meltponds drained (triangle), and when the ice concentration dropped below $90 \%$ for more than three consecutive days (diamond). Notice how the timings of snowmelt and meltpond drainage vertically align across the Clusters and Solo platforms, whilst there is a large separation in time in the ice concentration dropping below $90 \%$ and basal melt starting between the northerly clusters (C2 and C1) and the southerly platforms (C3, S1 and S2). 

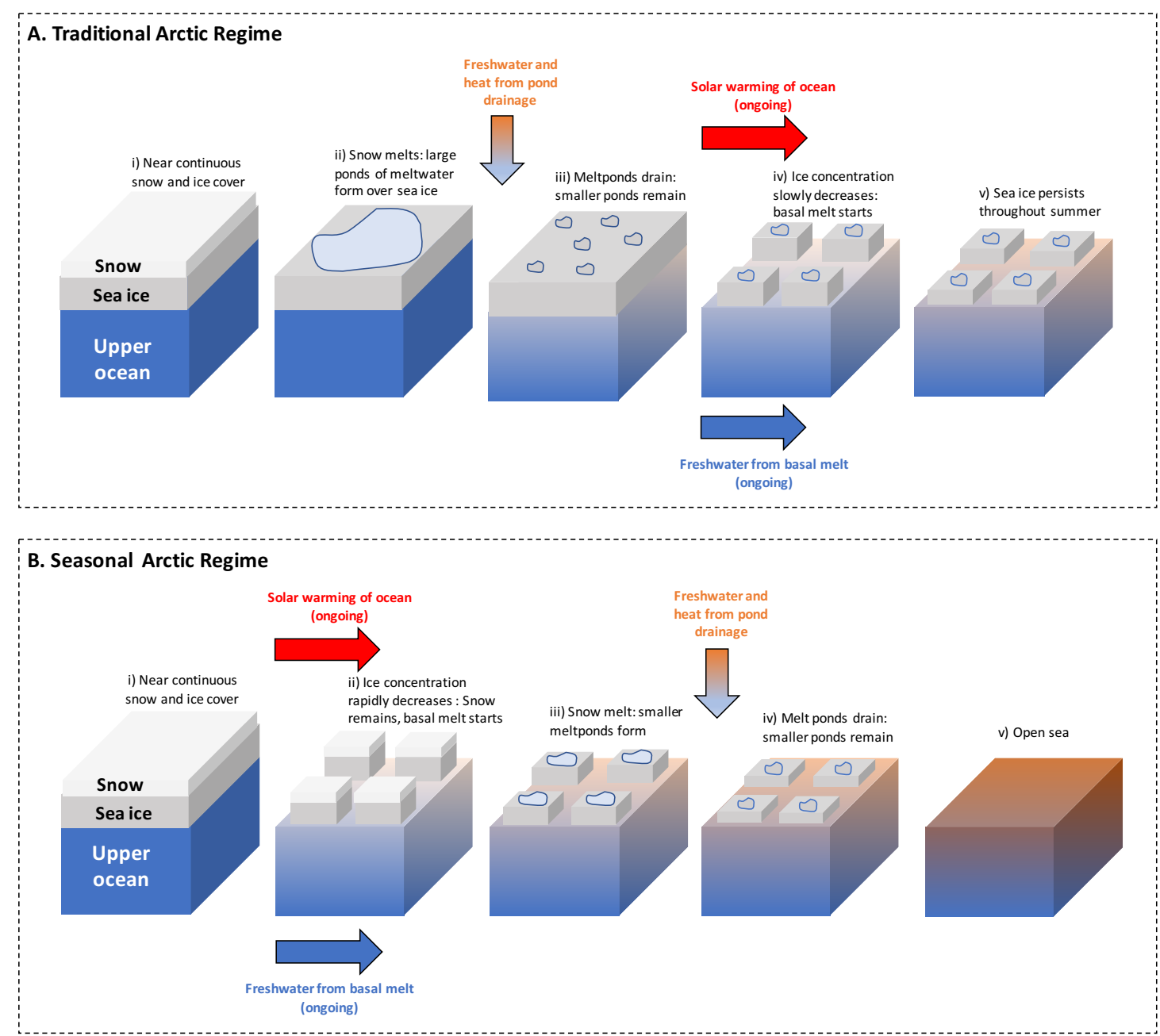

Fig. 3. Schematic representation of the traditional and seasonal melt cycles. Melt season progresses from left to right. Top: traditional snowmelt - pond formation/drainage — basal melt cycle that has traditionally existed within a perennial ice dominated Arctic. Bottom: the basal melt —snowmelt—pond formation/drainage scenario that may exist within a seasonal ice dominated Arctic. 

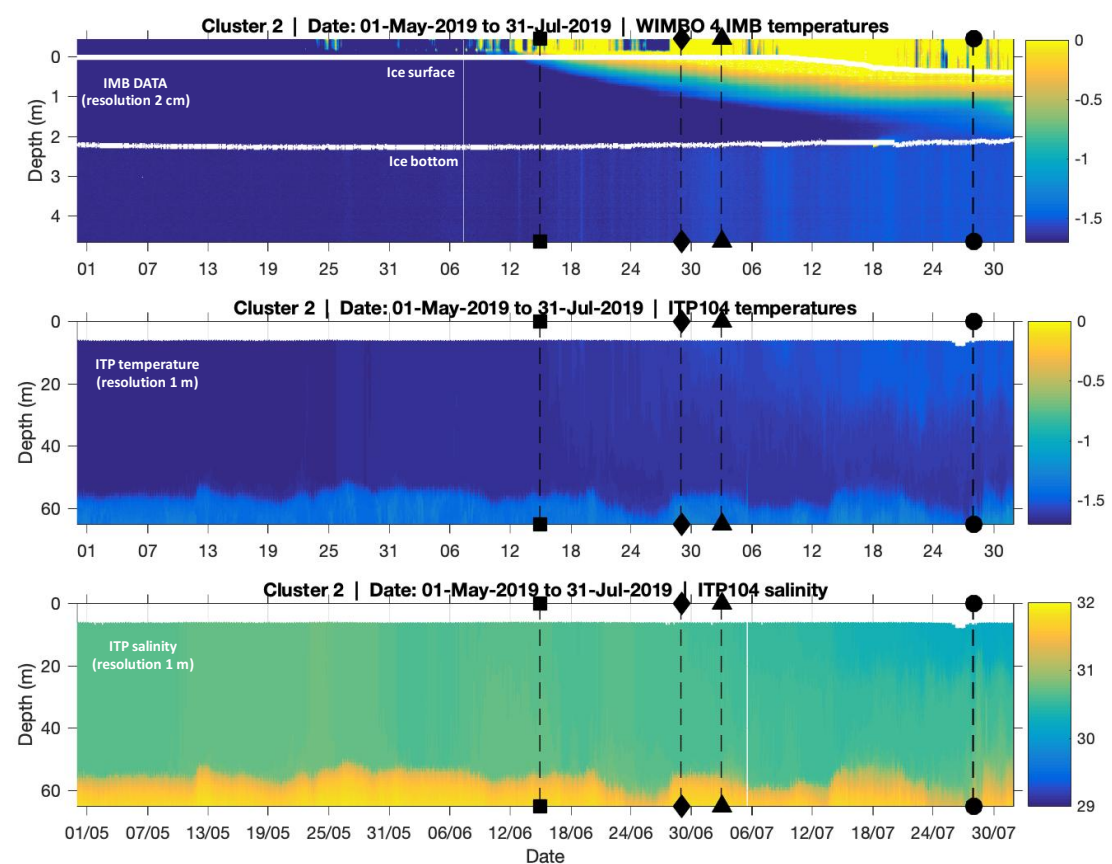

Fig. 4a. Temperature and salinity properties for the northern C2 between May1 and July 31, 2019. Scales are the same as in Fig 4b which shows similar properties for the southern C3. The black dotted lines with symbols identifies when basal melt started (circle), when snowmelt started (square), when the meltponds drained (triangle), and when the ice concentration first dropped below $90 \%$ for more than three consecutive days (diamond). Top: Air, snow, sea ice and upper-ocean temperatures from IMB on WIMBO4 (white lines represent the bottom and top of the sea ice); Middle: Upper-ocean temperatures from ITP104 profiler; and Bottom: Upper-ocean salinity from ITP104 profiler
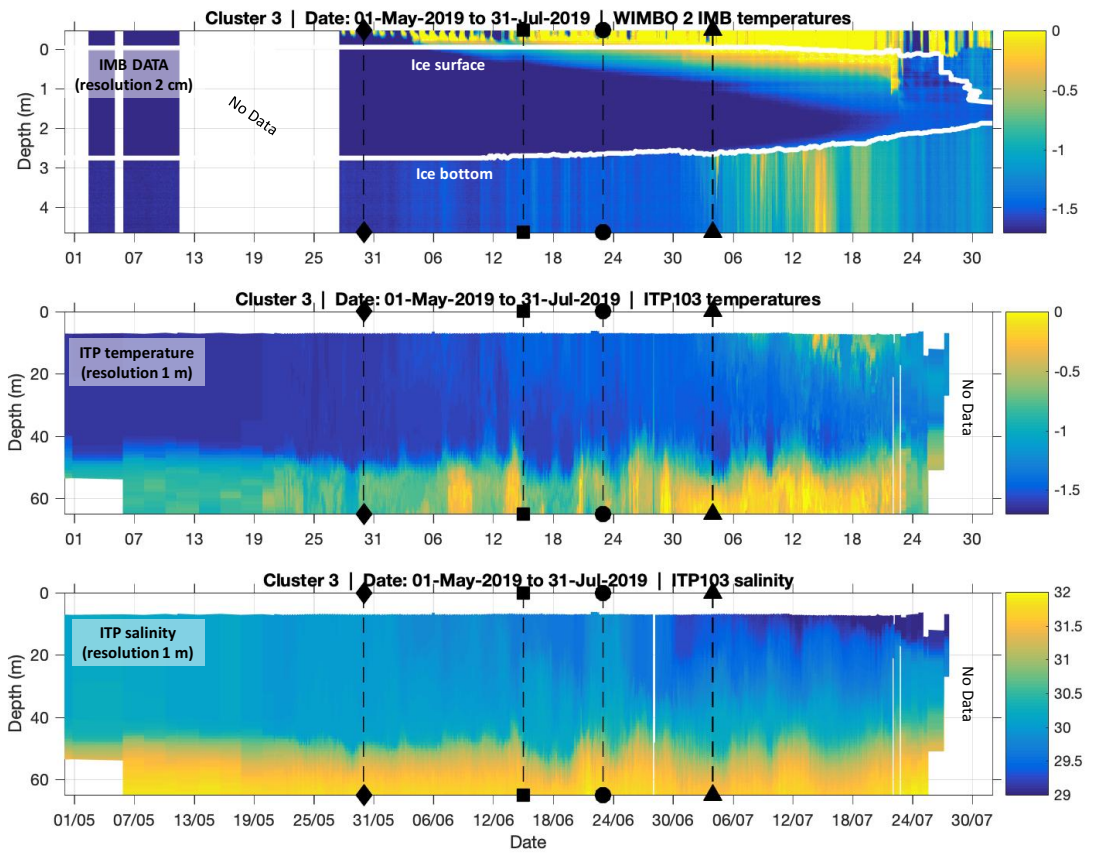

Figure 4b. As above but for the southern Cluster 3, but using WIMBO2 and ITP-103 data 

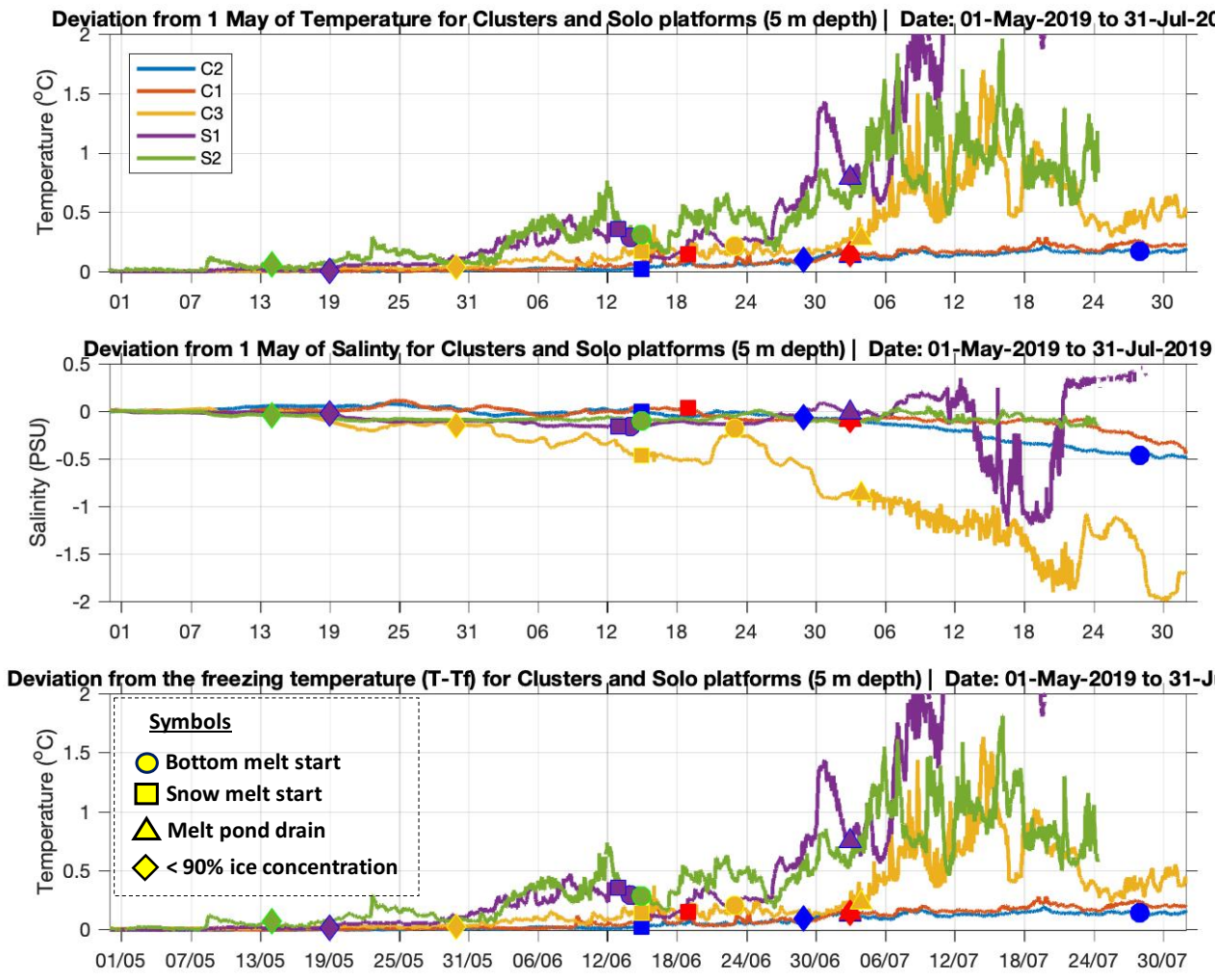

Fig. 5. Deviation of temperature and salinity from their May 1 values over the subsequent three months, along with the deviation of temperature $(\mathrm{T})$ from its freezing point $\left(\mathrm{T}_{\mathrm{f}}\right)$ at $5 \mathrm{~m}$ depth, for all Clusters and Solo sites. Timeline is from May 1 through to $31 \mathrm{July}$, and the $\mathrm{x}$-axis is limited in temperature to between 0 and $2^{\circ} \mathrm{C}$

Top: Temperature from the Microcat CTD at $5 \mathrm{~m}$ depth at C2: ITP104 (blue), C1:ITP103 (orange), and C3:ITP105 (yellow), along with $5 \mathrm{~m}$ temperature from S1:WIMBO1 (purple) and S2:WIMBO2 (green): The filled circles, squares, triangles and diamonds identifies when basal melt started, when snowmelt was initiated, when meltponds drained, and when the ice concentration dropped below $90 \%$ for more than three consecutive days.

Middle: As above, but for salinity.

Bottom: As above, but for deviation from freezing temperature $\left(T-T_{f}\right)$. 


\section{Supplementary Materials}

Fig. S1.

430

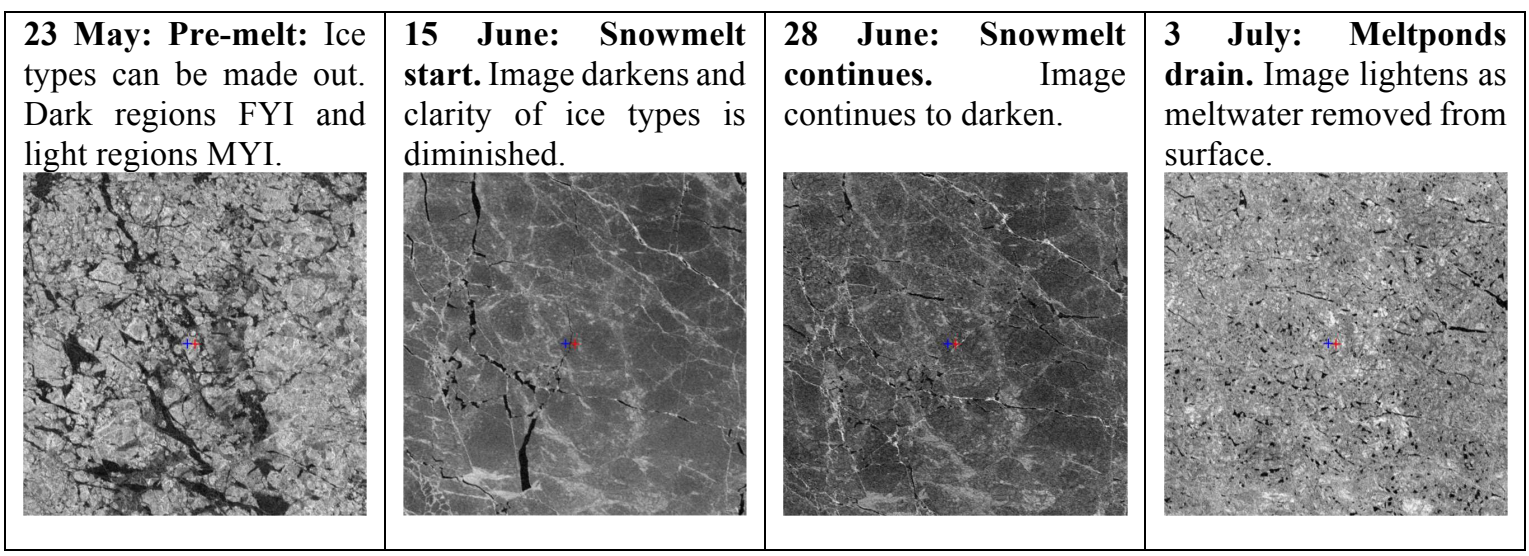

Fig. S1. A 10 x $10 \mathrm{~km}$ SAR image showing the ice conditions surrounding Cluster 2. The red cross shows the location of ITP104, and the blue cross shows the location of WIMB04. Working from upper left to bottom right we see the pre-melt conditions through to the first signs of snow melt, to continued melt, and then melt-pond drainage. 
Fig. S2.

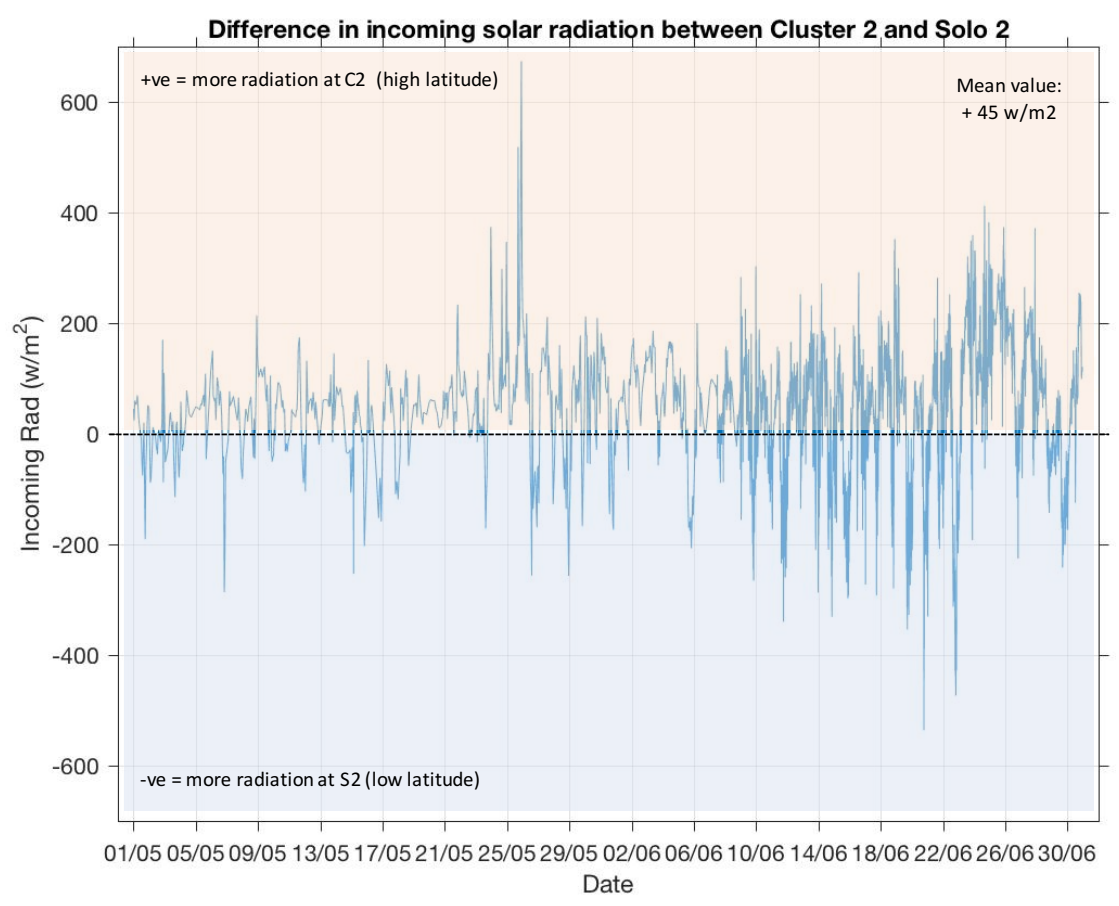

Fig. S2a. Difference between the solar radiation experienced at C2 (high ice concentration) and S2 (low ice concentration). In general, $\mathrm{C} 2$ experience $45 \mathrm{w} / \mathrm{m}^{2}$ more radiation than S2, despite being at a higher latitude.

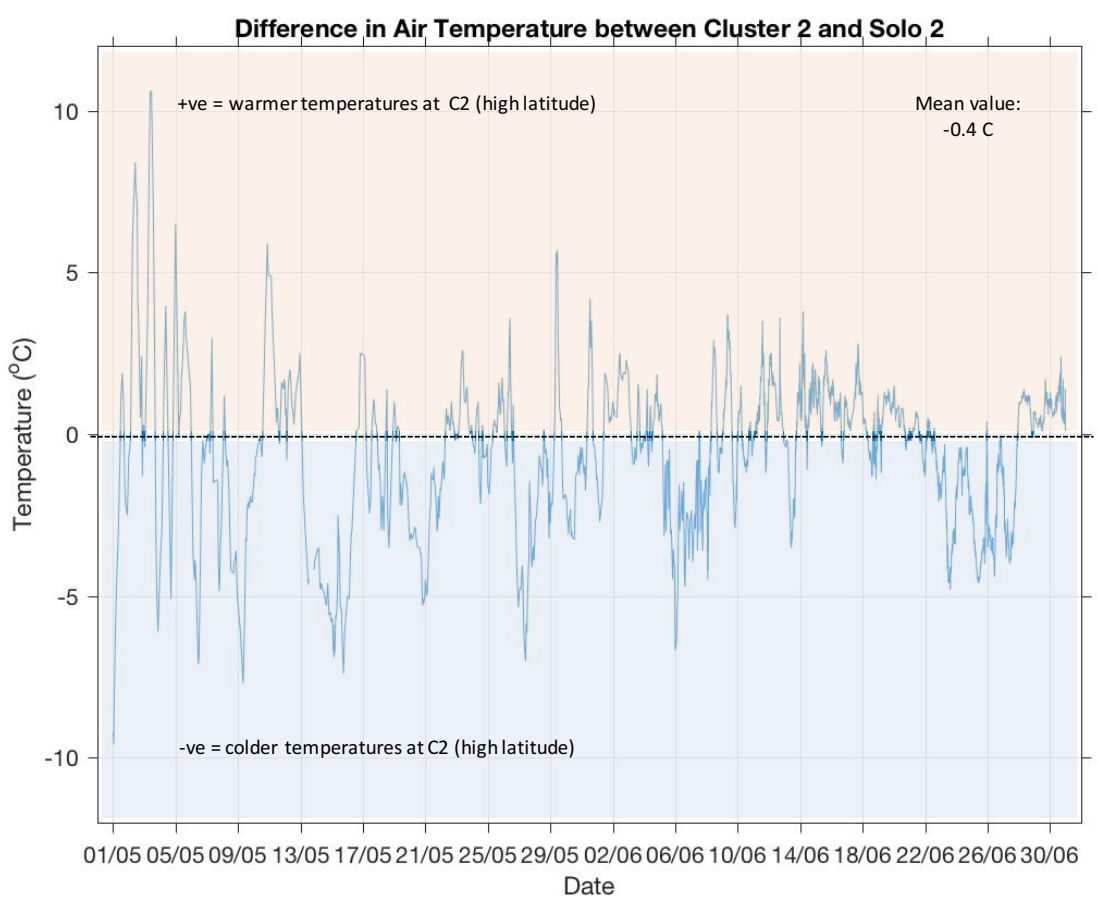

Fig. S1a. Difference between the air temperature experienced the northern C2 (high ice concentration) and that seen by southern platform S2 (low ice concentration). In general, C2 was about $0.4^{\circ} \mathrm{C}$ colder than the more southerly S2. 


\section{Figures}

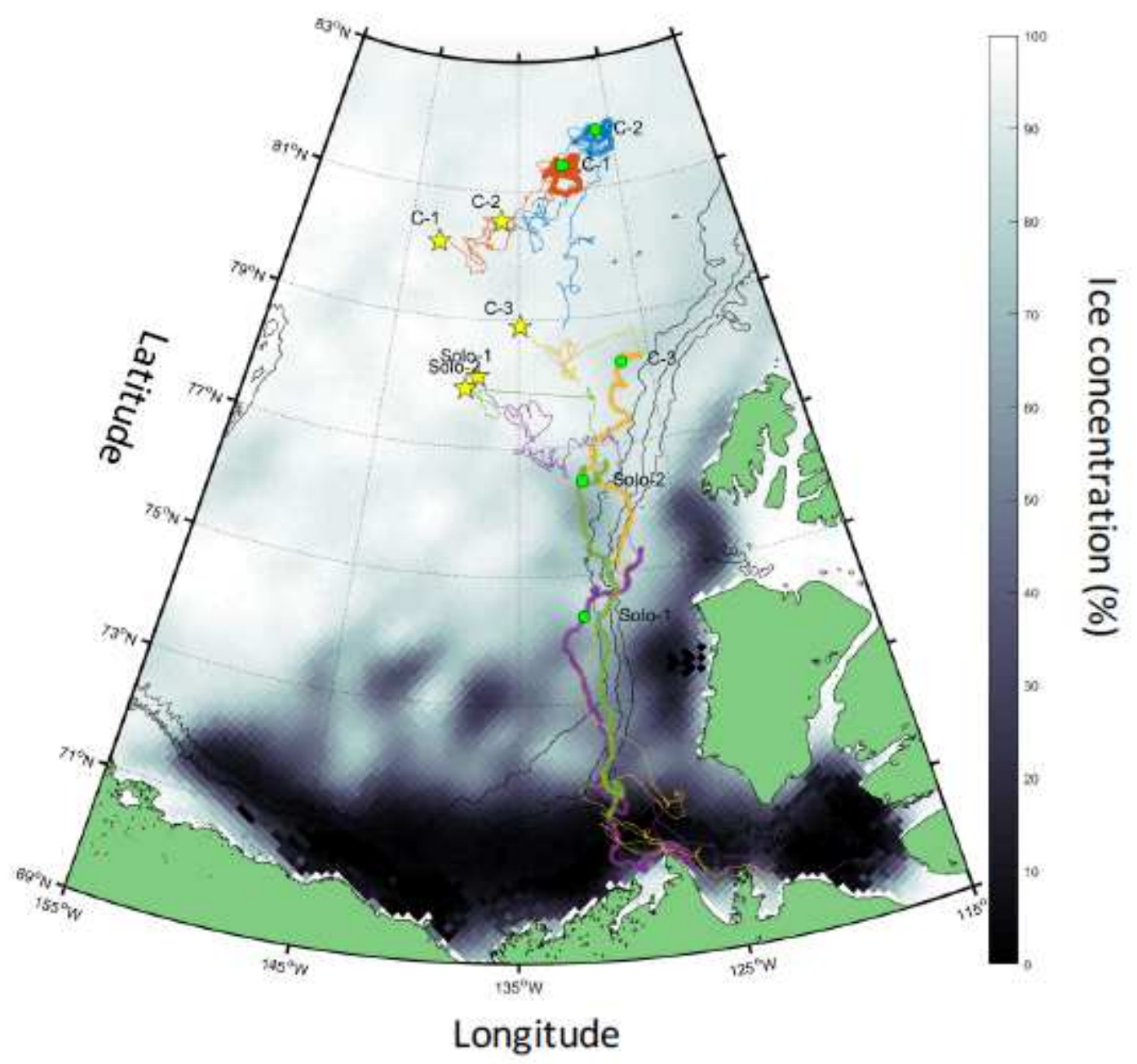

Figure 1

Drift tracks for Cluster 1 (red), Cluster 2 (blue), Cluster 3 (yellow), Solo1 (purple), Solo 2 (green). The thicker lines represent the drift track from 1 May to 31 July. Notice that Cluster 1 and 2 stay in the north, whilst all the other systems drift southward over time (especially S1 and S2 which are close to the coast by the end of July). The yellow star represents their deployment location, the green circle represents their location on 1 June 2019, the same date at the underling OSISAF ice concentration image (which runs from white or $100 \%$ ice concentration through to black $0 \%$ or open water). The $2000 \mathrm{~m}, 1000 \mathrm{~m}, 500 \mathrm{~m}$ bathymetric contour lines (in black) are also shown. 


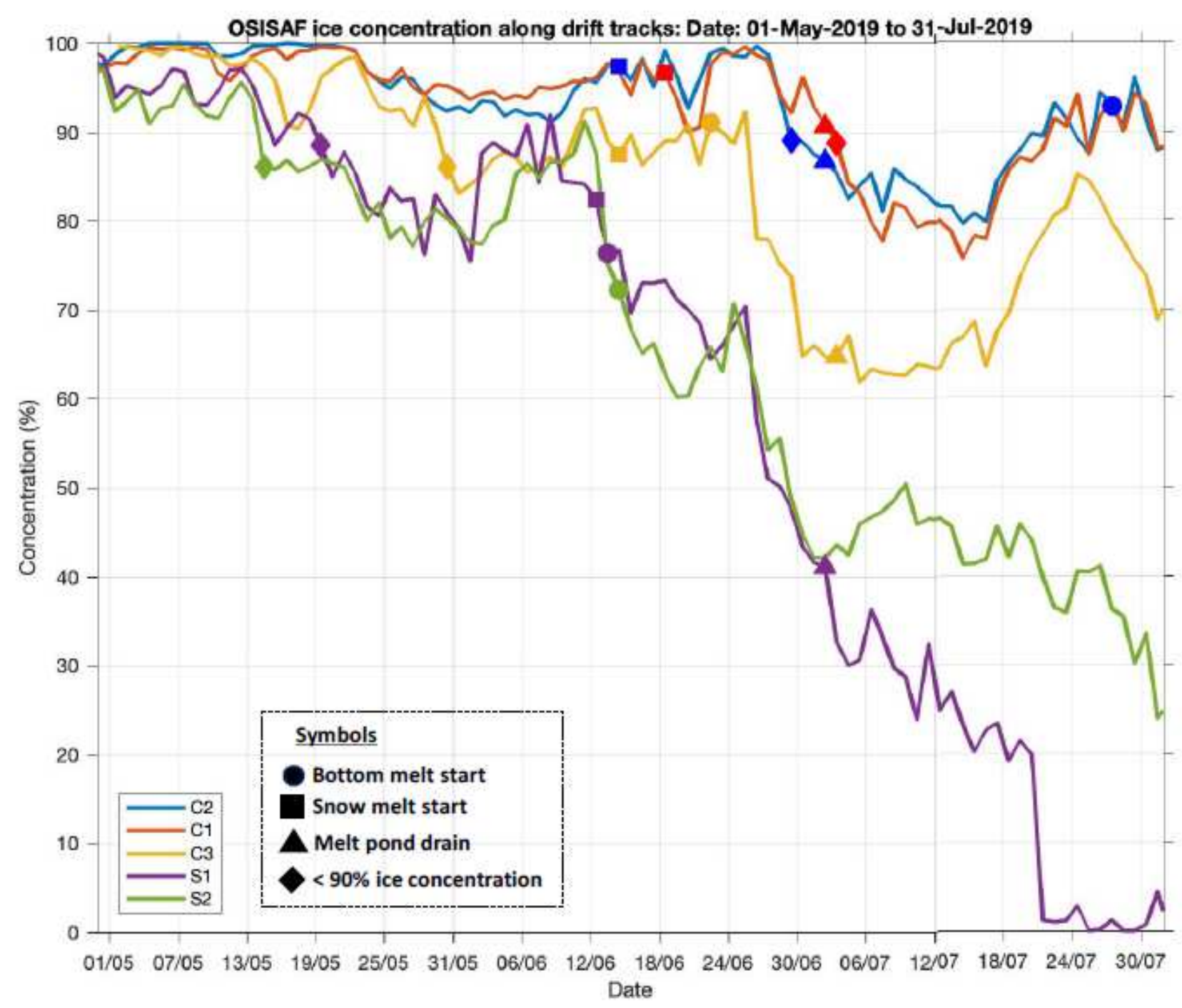

Figure 2

Graph showing ice concentration against date (from May 1 to July 31, 2019) along the track of each Cluster and Solo platform. Also shown is start of start of the basal melt (circle), snowmelt (square), when the meltponds drained (triangle), and when the ice concentration dropped below $90 \%$ for more than three consecutive days (diamond). Notice how the timings of snowmelt and meltpond drainage vertically align across the Clusters and Solo platforms, whilst there is a large separation in time in the ice concentration dropping below $90 \%$ and basal melt starting between the northerly clusters ( $\mathrm{C} 2$ and $\mathrm{C} 1$ ) and the southerly platforms (C3, S1 and S2). 

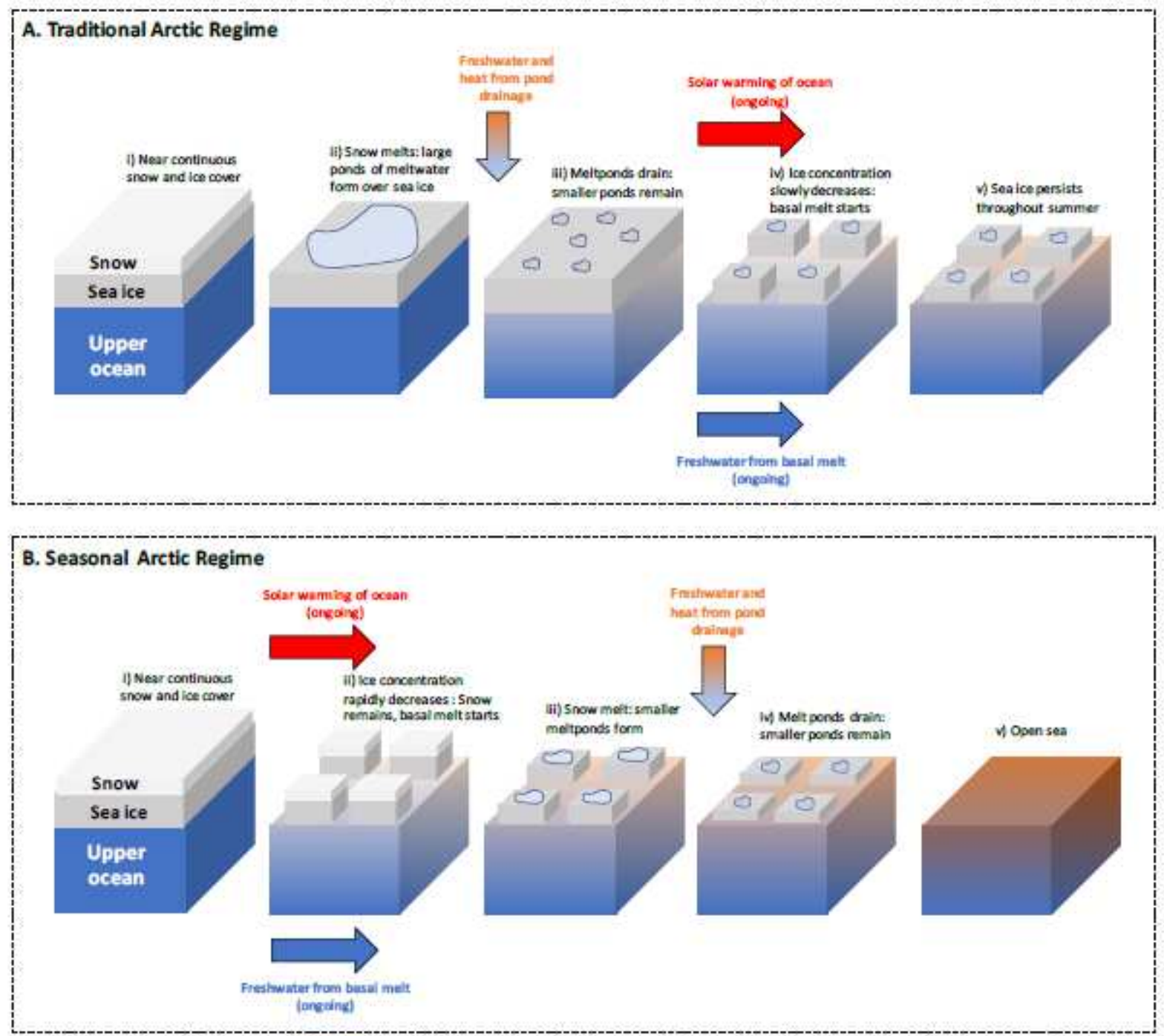

Figure 3

Schematic representation of the traditional and seasonal melt cycles. Melt season progresses from left to right. Top: traditional snowmelt-pond formation/drainage - basal melt cycle that has traditionally existed within a perennial ice dominated Arctic. Bottom: the basal melt-snowmelt-pond formation/drainage scenario that may exist within a seasonal ice dominated Arctic. 

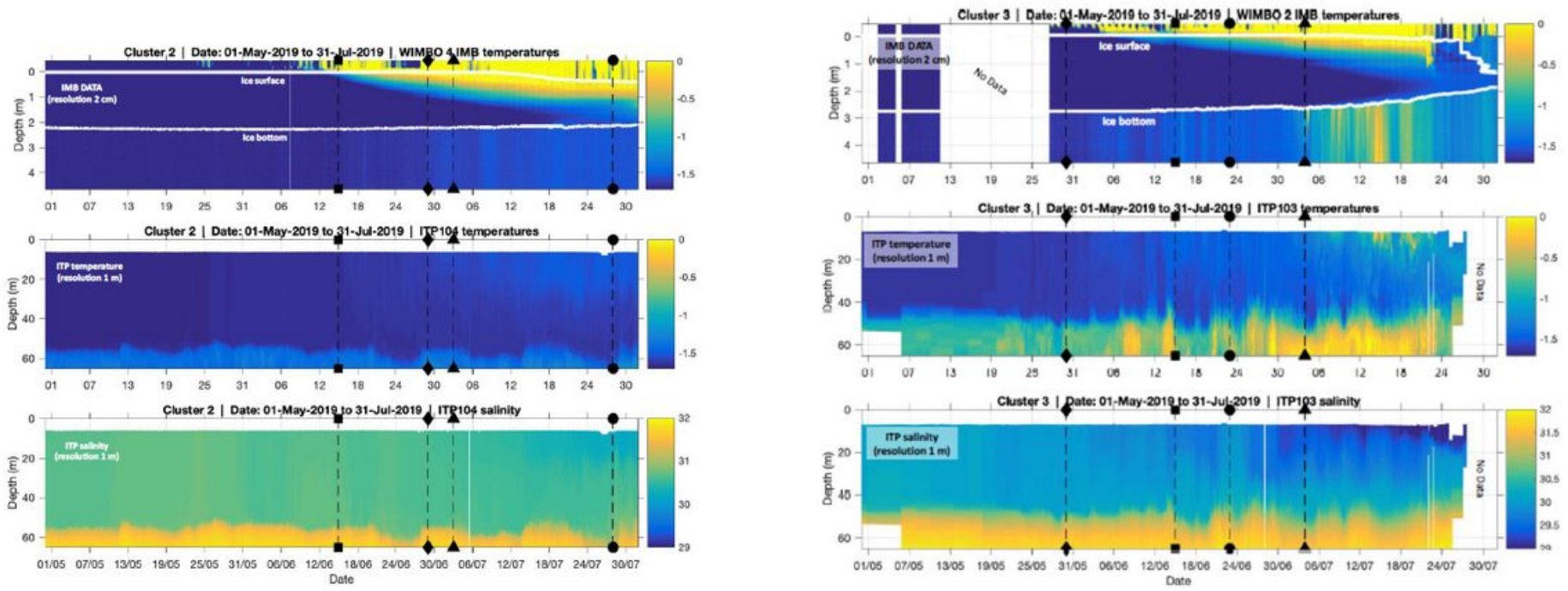

\section{Figure 4}

(Left)a. Temperature and salinity properties for the northern C2 between May1 and July 31, 2019. Scales are the same as in Fig $4 \mathrm{~b}$ which shows similar properties for the southern $\mathrm{C} 3$. The black dotted lines with symbols identifies when basal melt started (circle), when snowmelt started (square), when the meltponds drained (triangle), and when the ice concentration first dropped below $90 \%$ for more than three consecutive days (diamond). Top: Air, snow, sea ice and upper-ocean temperatures from IMB on WIMBO4 (white lines represent the bottom and top of the sea ice); Middle: Upper-ocean temperatures from ITP104 profiler; and Bottom: Upper-ocean salinity from ITP104 profiler (Right) 4b. As above but for the southern Cluster 3, but using WIMBO2 and ITP-103 data 

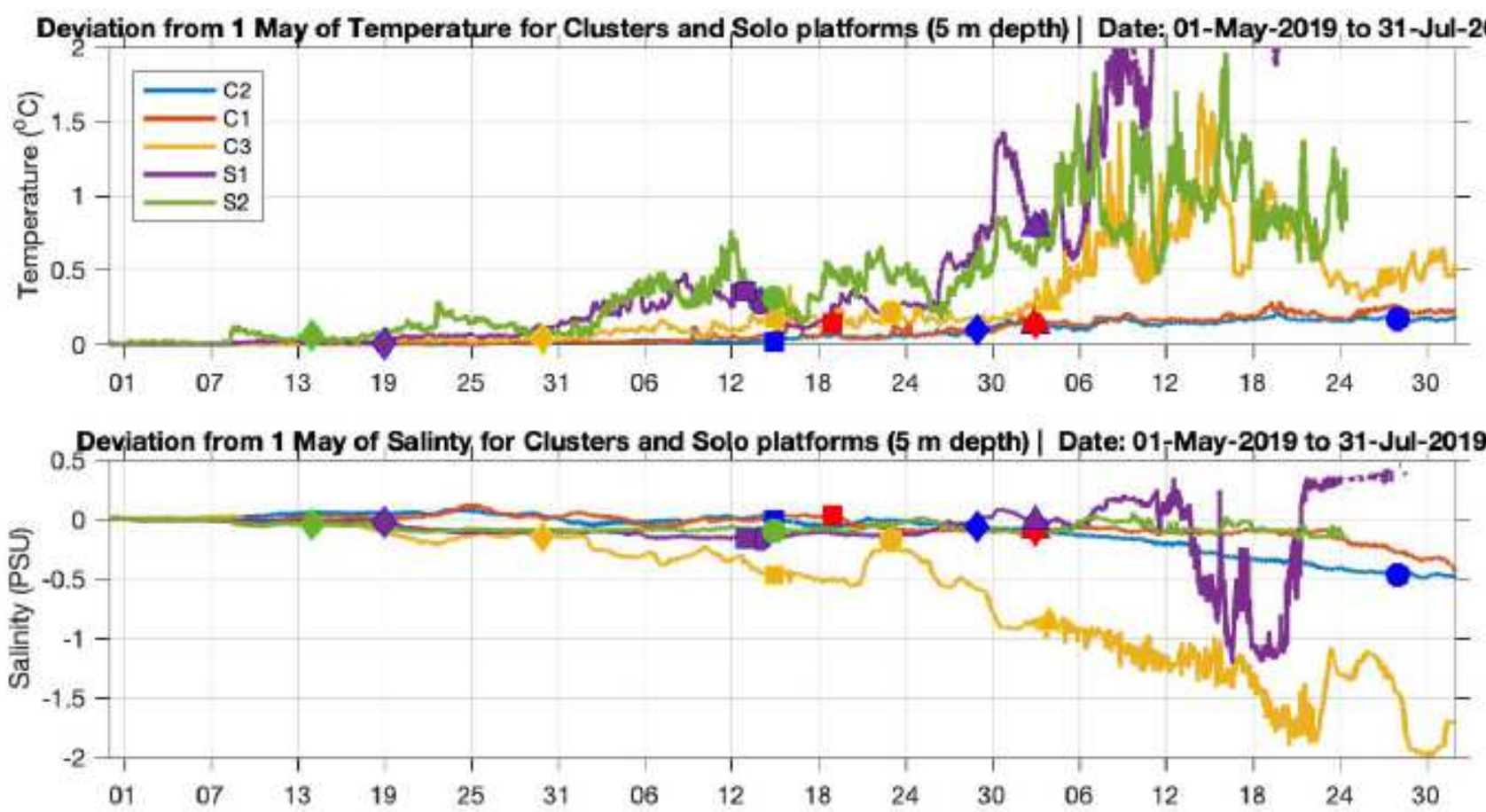

Deviation from the freezing temperature (T-Tf) for Clusters and Solo platforms (5 m depth) | Date: 01-May-2019 to 31 -Jul-2019

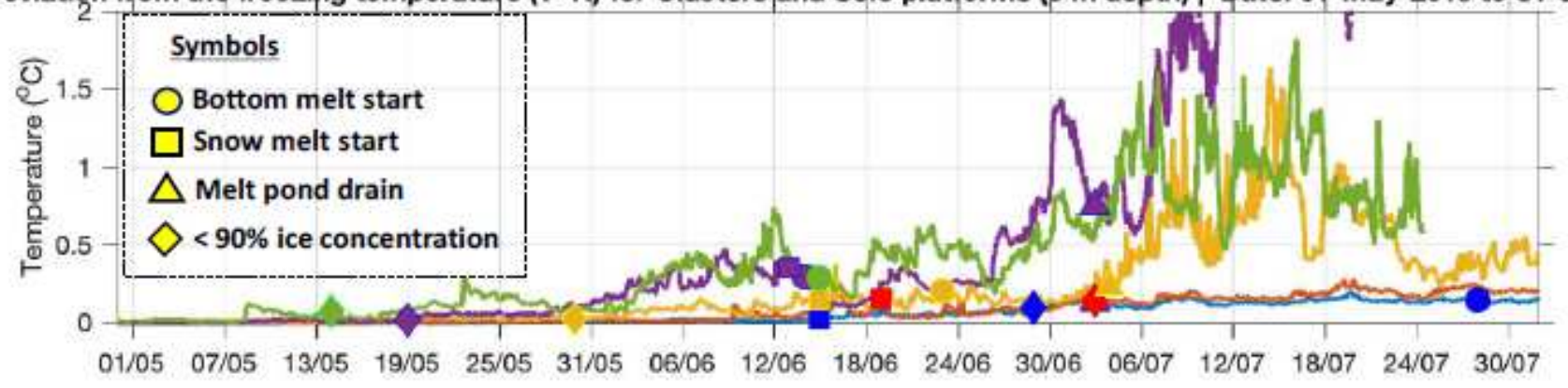

\section{Figure 5}

Deviation of temperature and salinity from their May 1 values over the subsequent three months, along with the deviation of temperature $(T)$ from its freezing point ( $T f$ ) at $5 \mathrm{~m}$ depth, for all Clusters and Solo sites. Timeline is from May 1 through to 31 July, and the $x$-axis is limited in temperature to between 0 and $2^{\circ} \mathrm{C}$ Top: Temperature from the Microcat CTD at $5 \mathrm{~m}$ depth at C2: ITP104 (blue), C1:ITP103 (orange), and C3:ITP105 (yellow), along with $5 \mathrm{~m}$ temperature from S1:WIMB01 (purple) and S2:WIMBO2 (green): The filled circles, squares, triangles and diamonds identifies when basal melt started, when snowmelt was initiated, when meltponds drained, and when the ice concentration dropped below $90 \%$ for more than three consecutive days. Middle: As above, but for salinity. Bottom: As above, but for deviation from freezing temperature (T-Tf).

\section{Supplementary Files}

This is a list of supplementary files associated with this preprint. Click to download. 
- FigS1.png

- FigS2final.jpg 